\title{
Legal Analysis of the Implementation of Child Inmates Coaching in Class II-B Correctional Institution of Langsa City, Indonesia
}

\author{
Wilsa Wilsa \\ Doctoral Program of Legal Studies, Sultan Agung Islamic University, Semarang, Indonesia \\ E-mail : wilsauyubhasan@yahoo.co.id
}

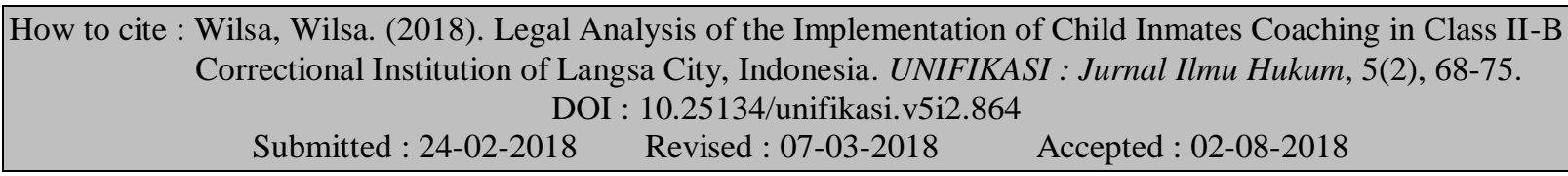

\begin{abstract}
Republic of Indonesia Law Number 12 of 1995 concerning Corrections assets that correctional coaching is carried out based on several principles, namely: guidance; treatment and service equality; education and counseling; respect for human dignity; and guarantee to keep in touch with families and certain people. Class II-B Correctional Institution of Langsa city is an adult Correctional Institution. The purpose of this study is to analyze the implementation of child inmates coaching in Class II-B Correctional Institution of Langsa city and find out the efforts done to overcome constraints in the implementation of child inmates coaching. The method used in this research was Juridical Empirical research method that examines the implementation of normative legal behavior relating to the implementation of child inmates coaching in Class II-B Correctional Institution of Langsa city. The results showed that the implementation of child inmates coaching does not correspond to child's rights since, in addition to an over capacity of the correctional institution, child inmates do not get personality and self-reliance coaching. In conclusion, the child inmates' coaching which is expected to be well implemented is far from the expectations since it does not correspond to child's rights. Therefore, it suggested that the government can immediately build a special Correctional Institution for child inmates with appropriate facilities and infrastructure since children are the next generation of a nation
\end{abstract}

Keywords: Coaching, Child inmates, Class II-B Correctional Institution of Langsa City

\section{Analisis Hukum Pelaksanaan Pembinaan Narapidana Anak di Lembaga Pemasyarakatan Kelas II-B Kota Langsa, Indonesia}

\begin{abstract}
Abstrak : Undang-undang RI Nomor 12 Tahun 1995 tentang Pemasyarakatan dimana menegaskan pembinaan pemasyarakatan dilaksanakan berdasarkan beberapa asas yaitu : Pengayoman ; Persamaan perilaku dan pelayanan ; Pendidikan dan pembimbingan ; Penghormatan harkat dan martabat manusia ; Kehilangan kemerdekaan satu-satu nya penderitaan ; Terjaminnya hak untuk tetap berhubungan dengan keluarga dan orang-orang tertentu . Lembaga Pemasyarakatan kelas II-B Kota Langsa adalah lembaga Pemasyarakatan Dewasa, Tujuan penelitian ini adalah mengetahui dan menganalisis bagaimana pelaksanaan pembinaan hak-hak narapidana anak di Lembaga Pemasyarakatan kelas II-B Kota Langsa dan bagaimana upaya yang dilakukan untuk mengatasi kendala dalam pelaksanaan pembinaan narapidana anak. Metode penelitian yang digunakan dalam penulisan ini yaitu Metode penelitian yang digunakan yaitu Yuridis Empiris yaitu mengkaji mengenai implementasi ketentuan hukum normatif (perundang-undangan) yang berhubungan dengan pembinaan narapidana anak di lembaga pemasyarakatan Kelas II-B kota Langsa. Hasil penelitian pelaksanaan pembinaan narapidana anak tidak memenuhi hak-hak narapidana anak, karena selain keadaan lembaga pemasyarakatan over kapasitas, kenyataan apa yang diharapkan tidak terealisasi dengan baik, karena narapidana anak tidak mendapatkan pembinaan kepribadian dan pembinaam kemandirian. Simpulan secara faktual pembinaan narapidana anak yang diharapkan tidak terlaksana dengan baik, jauh dari harapan pemenuhan hak-hak narapidana anak., disarankan pemerintah segera membangaun Lembaga pemasyarakatan khusus anak dengan sarana dan prasarana yang layak. Mengingat anak adalah generasi yang berpotensian bagi bangsa
\end{abstract} Kata Kunci: Pelaksanaan Pembinaan, Narapidana Anak, Lembaga Pemasyarakatan Kelas II-B Kota Langsa

\section{INTRODUCTION}

Children have a strategic role as the next generation of a nation. Children should be given special attention from an early age until adolescence to adulthood. Children are human resources who have the potential to continue the ideals of a nation in the future. Children need guidance in ensuring their physical, social, and mental growth in a gradual and balanced manner. As a person who is unique and has distinctive characteristics, a child can act based on his own feelings, thoughts, and desires. In addition to his own will, a child's actions or behaviors can also be influenced by the surrounding environment. Children can act out of control; they can commit criminal acts violating the law ${ }^{1}$. The purpose of Correctional Institution is to guide prisoners for the better, so

1 Komar Hidayat, Yunusrul Zen dan Diding Rahmat, Analisis Yuridis Terhadap Kebijakan Diversi Pemerintah Daerah Dalam Perlindungan Anak Di Kabupaten Kuningan, Jurnal Unifikasi, Vol. 04, Nomor 02, Juli 2017, Kuningan, FH. Uniku, pp. 87. 
that they can become useful people when they return to the society ${ }^{2}$.

For this reason children need extra attention since a nation will only develop if the next generation is potential. It can be done by paying attention to child's prosperity and protection so that their physical and psychological aspects can grow and develop optimally. Therefore, child coaching is needed to be done continuously, both physically, mentally and socially as well as providing protection from all possibilities that will endanger them in the future.

Discussing about legal studies cannot be separated from the understanding of learning, examining, investigating, thinking, testing, and studying ${ }^{3}$. Indeed, child's guidance consists of 3 (three) main activities, namely: Coaching, Development and Protection. Child coaching is an effort to provide the best treatment for child growth, Development is to help children to develop their abilities and talents, while protection is all activities done to ensure child be able to grow naturally and physically and free from all threats, obstacles and disturbances. ${ }^{4}$ In terms of the purpose of this protection, in accordance with the Beijing Rules, the child inmates are avoided from imprisonment. Criminal imprisonment becomes the last effort because criminal imprisonment to child inmates causes the child entering correctional institution. ${ }^{5}$

Class II-B Correctional Institution of Langsa City is a correctional facility designated for adult inmates. One of the objectives and functions of the correctional institution is a place for inmates coaching. The legal basis of

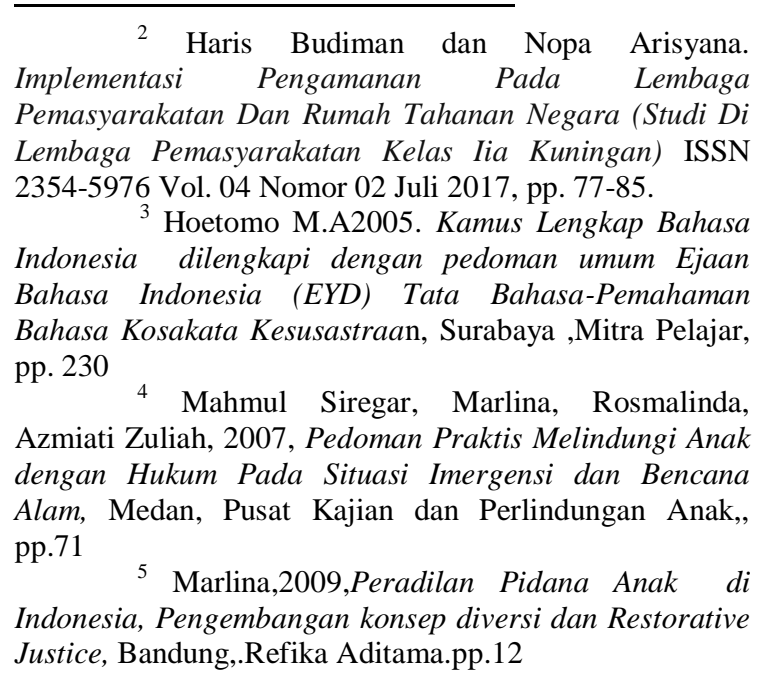

the inmates coaching is the Law No. 12 of 1995 concerning Corrections. The law aims to provide a strong legal basis for the correctional system which has replaced the old provisions and legislation that are still based on the prison system and will regulate new things that are considered more suitable with Pancasila values and the 1945 Constitution of the Republic of Indonesia. Based on the description above, the problems discussed in this research are formulated into the following questions:

1. How is the implementation of child inmates coaching in Class II-B Correctional Institution of Langsa city, Indonesia?

2. What efforts have been done to overcome the constraints in the implementation of child inmates coaching in Class II-B Correctional Institution of Langsa city, Indonesia?

\section{METHOD}

The method used in this research was empirical juridical research method which is reviewing the implementation of normative legal provisions (legislation) relating to child inmates coaching. This research aims to examine the extent to what a particular law, vertically or horizontally, is implemented. It also includes an equivalent law in the same field which regulates the child inmates coaching in Class II-B Correctional Institution of Langsa City, Indonesia. The data used were primary and secondary data.

\section{RESULTS AND DISCUSSION \\ The Implementation of Child Inmates Coaching in Class II-B Correctional Institution of Langsa City, Indonesia}

The term "correctional" is a substitute for "imprisonment" and the term "prison" becomes "a correctional institution". This replacement is not just a change of terms/names, but it is also a "system" and "treatment" to the inmates. Moreover, the term "Corrections" contains certain "goals", namely educating, upbringing and guiding the inmates who will return to the society as a better person after their criminal term $^{6}$. Then, the correctional institution

\footnotetext{
${ }^{6}$ Syamsul Hilal, "P4 adalah Mutlak perlu Bagi Setiap Aparatur Pemasyarakatan Sebagai Pelaksana Dan
} 
(LAPAS) is the place to carry out inmates coaching and correctional officers as one of the technical implementing units (UPT) of correctional facilities (Law No.12 of 1995). ${ }^{7}$

Correctional Institution, hereinafter referred to as LAPAS, is a place to carry out inmates coaching and corrections. ${ }^{8}$ The promulgation of Law No. 12 of 1995 concerning Corrections provides an important meaning for the development. The correctional system which is based on Pancasila and the 1945 Constitution provides a strong legal basis in implementing "correctional system" which has been used to guide inmates since 1964 to replace the "prison system".

The Correctional System implemented in Indonesia is based on Pancasila which is not only used as the basis of the state, but also as a life view of the nation, the soul and personality of the nation, the goals to be achieved by the nation, and as a noble agreement of the Indonesian citizens ${ }^{10}$. Therefore, Barda Nawawi Arief and Muladi state that the relationship between the determination of criminal sanctions and the purpose of criminal prosecution is an important point in determining criminal political planning strategies. The purpose of prosecution can then be the basis for determining ways, suggestions or actions to be done. ${ }^{11}$

Correctional Institutions through the correctional system provide treatment to inmates through a coaching pattern ${ }^{12}$ because the purpose of criminal prosecution is to awaken inmates or child inmates to regret their actions and return them to become citizens who obey law and uphold moral, social and religious values so that a safe, orderly and peaceful life can be realized.

Sebagai Abdi Masyarakat, Majelis Pemasyarakatan, 21 Maret 1979,pp.18

7 A. Josias SIMON R -Thomas Sunaryo , 2010 Studi Kebudayaan Lembaga Pemasyarakatan Indonesia, Bandung, Lubuk Agung, pp.14

${ }^{8}$ Dwidja Priyatmo, 2006 Sistem Pelaksanaan Pidana Penjara Di Indonesia, Bandung, Refika Aditama, halaman 107

${ }^{9}$ Ibid, pp. 28

${ }^{11}$ Muladi dan Barda nawawi Arief, 1998, TeoriTeori dan Kebijakan Pidana, ,Bandung, PT.Alumi , hlm 96

12 Krisna Sitanggang, Pembinaan Terhadap Narapidana (Studi di Lembaga Pemasyarakatan Kelas II B Kota Langsa) https://jurnal.usu.ac.id/index.php/jmpk/article/view/8184/ 3544 diakses pada tgl 6 februari 2018
Law Number 12 of 1995 concerning "Corrections" describes that child inmates should get coaching in child correctional institutions. The placement of child inmates into child correctional institutions is separated based on their status, namely criminal children, state children and civilian children. The Correctional System also determines the duration of the implementation of child inmate coaching based on their respective status which consists of:

a. The criminal children are children who serve a criminal based on the court's decision in child Correctional Institution at the latest up to the age of 18 (eighteen) years old.

b. State children are children who are handed over to the State to be educated based on the court's decision and placed in child Correctional Institution at the latest up to the age of 18 (eighteen) years old.

c. Civil children are children who are based on the court's decision placed in child Correctional Institution for a maximum of 6 months for those who are not yet 14 years old, and for a maximum of 1 year for those who are 14 years old at the time of placement and it can be extended up to 18 years old. ${ }^{13}$

It has also been confirmed at the Conference of Prison Inspectors and Directors throughout Indonesia on April 27, 1964. From the Conference, it can be seen that in the correctional system, the purpose of placing the inmates in Correctional Institutions is to be coached and educated, not to be tortured, to return to the right path.

To achieve the goals of coaching towards child inmates who are placed in adult correctional institutions, the coaching system is done the same as adult inmates coaching which is guided by the stipulated provisions. Based on Law No. 12 of 1995 concerning Corrections, inmates coaching must be done based on the following principles:

a. Guidance,

b. Treatment and service equality,

c. Education and coaching,

d. Coaching,

e. Respect for human dignity,

f. Losing independence is the only suffering,

${ }^{13}$ Undang-Undang Republik Indonesia Nomor 12 Tahun 1995 tentang pemasyarakatan, 


\section{g. Guarantee to keep in touch with families and certain people ${ }^{.14}$}

The explanations of the principles mentioned above are: "Guidance" is the treatment given to the inmates in order to prevent them from the possibility of repeating criminal acts and to guide them to become a better society member. "Treatment and service equality" is the provision of the same treatment and services to all inmates without any discrimination. "Education" is that education and "coaching" are carried out based on Pancasila, including the cultivation of a family spirit, skills, spiritual education, and the opportunity to worship. "Respect for human dignity" is that as a lost person, the inmates should be treated as human beings. "Losing independence is the only suffering" is that the inmates should be in the Correctional Institutions for a certain period of time so that they have the opportunity to improve it. During their prosecution period, the inmates retain their rights as human beings. In other words, their civil rights are still protected, such as the right to health care, eating, drinking, clothing, beds, exercising, skills, sports, or recreation. "Guarantee to keep in touch with families and certain people" is that the inmates should be brought closer and introduced to the society, and should not be alienated from the society even though they are in Correctional Institutions. They can do such activities, like community visits, entertainment in the Correctional Institutions, and the opportunity to gather with friends and family. ${ }^{15}$

Furthermore, child inmates coaching issue is inseparable from how to protect the basic rights of the child even though the child is an inmate placed in a correctional institution. In this sense, Law Number 11 of 2012 concerning child criminal justice system describes the principle of legal protection for the child which should correspond to the convention on the rights of child as confirmed by the Indonesian government with Presidential Decree Number 36 of 1990 concerning the ratification of the convention on the rights of child ${ }^{16}$.

14 C. D.Jisman Samosir, 2016, Penologi dan Pemasyarakatan,Nuansa Aulia, Banadung, pp 199

${ }^{15}$ Dwidja Priyatmo, 2006, Sistem Pelaksanaan Pidana penjara di Indonesia, Bandung, Refika Aditama, , halaman 107

${ }^{16}$ R, wiyono,2016, Sistem Peradilan Pidana Anak Di Indonesia, Jakarta ,Timur, Sinar Grafika, pp. 3032
By considering the Convention on the Rights of Child in the enactment of Law Number 11 of 2012 (Law on child criminal justice system) and its general explanation, then both directly and indirectly, Law Number 11 of 2012 is the elaboration of the Convention on the Rights of Child. Therefore, to implement Law Number 11 of 2012, the law enforcement officers should also pay attention to the provisions contained in the Convention on the Rights of Child, namely to protect children's rights. Article 2 of the Law of the Republic of Indonesia Number 35 of 2014 concerning Amendments to Law Number 23 of 2002 concerning Child Protection determines that the principles of the Convention on the Rights of Child include the following:

1. Non-discrimination. The principle of nondiscrimination is that all rights recognized in the Convention on the Rights of Child should be applied to every child without any discrimination ${ }^{17}$. This principle is stated in Article 2 paragraph (1) of the Convention on the Rights of Child, namely: "The participating countries will respect and guarantee the rights listed in this convention for every child in their jurisdiction without discrimination in any form, regardless of race, skin color, gender, language, religion, political views or other views, nationality, ethnic or social origin, ownership, disability or not, birth or other status either from the child himself or from his parents". Article 2 paragraph (2) states the participating countries will take all necessary efforts to ensure that the child is protected from any type of discrimination or punishment based on status, activities, opinions expressed or beliefs of the child's parents, their legal guardian or family member". (Paragraph 2).

2. The best interest for the child. In this case, the principle of the best interest for the child is that in all actions related to the child that are carried out by the government, community, legislative and judicial institutions, the best interests for the child should become the main consideration $^{18}$. As stated in Article 3

17 Hadi Supeno,2010, Kriminalisasi Anak, Jakarta, Gramedia Pustaka Utama, cetakan ke-1 pp. 54

${ }^{18}$ Penjelasan Pasal 2 Undang-Undang Republik Indonesia Nomor 35 Tahun 2014 Tentang Perubahan Atas Undang-Undang Nomor 23 Tahun 2002 Tentang Perlindungan Anak 
paragraph (1) that in all actions related to the child that are carried out by the social welfare institutions or legislative institutions, the best interests for the child should become the main consideration (Article 3 paragraph (1)).

3. The rights to live, survival, and development. Development is the basic human right for a child protected by the state, government, society, family and parents. ${ }^{19}$ Article 6 paragraph (1) state the participating countries recognize that every child has inherent rights to life. Article 6 paragraph (2) contains provision that the participating countries will guarantee the child survival and development to the maximum extent.

4. Respect for the views of the child. In this case, the principle of respect for the views of the child is a respect for children's rights to participate and express their opinions in decision making, especially when it comes to matters affecting their lives ${ }^{20}$. Children's opinions, especially when it comes to matters affecting their lives, need to be considered in every decision making. This principle is stated in Article 12 paragraph (1).

The objective of the Convention on the Rights of Child is the participating countries will ensure that children who have their own views will have the right to express their views freely in all matters affecting them, and that views will be valued according to their age and maturity. This principle is in accordance with the implementation of Article 6 of the Convention on the Rights of Child which is then explicitly adopted as well as the source principles contained in the Child Protection Act. Moreover, this principle is also stated in legal norms Article 4, Law of the Republic of Indonesia Number 35 of 2014 concerning amendments to law Number 23 of 2002 concerning child protection.

If being compared, the legal norm in Article 4 of the Child Protection Act refers to and derives from Article 28 B Paragraph $1 \& 2$

${ }^{19}$ Penjelasan Pasal 2 Hurup C Undang-Undang Republik Indonesia Nomor 35 Tahun 2014 Tentang Perubahan Atas Undang-Undang Nomor 23 Tahun 2002 Tentang Perlindungan Anak

${ }^{20}$ Penjelasan Pasal 2 Hurup D Undang-Undang Republik Indonesia Nomor 35 Tahun 2014 Tentang Perubahan Atas Undang-Undang Nomor 23 Tahun 2002 Tentang Perlindungan Anak of the 1945 Constitution of the Republic of Indonesia. All of them are the real terms of the principles of inmates coaching concept in a correctional institution which aims to form a better and dignified personality ${ }^{21}$.

In terms of child prisoners coaching, the condition shows that the policy of child inmates' placement in adult Correctional Institution illustrates how bad the condition of child inmates because they are vulnerable to all violence acts and threatened with learning criminal from adults. Actually, the inmates coaching in Correctional Institutions is one of the government's efforts to educate child inmates. It is done with the hope that children who are placed in Correctional Institution can be aware of their mistakes and will not repeat the same mistakes. These guidance and protection efforts can be seen from the Decrees issued by the government through the Law, Government Regulation, Legislation, and Decree of the Minister of Justice.

The implementation of child inmates coaching cannot be equated with adult inmates coaching because of the physical and mental differences of the child. With the special regulation on child inmate coaching, it is expected that the child will receive protection so that they can develop their abilities and talents, and be free from any kind of threats and disturbances. Child inmates placed in Correctional Institution should not be punished, but they should be educated to be a better person. It has been confirmed by Law Number 12 of 1995 concerning Corrections which states that:

" Child inmates are placed in child correctional institutions. The placement of child inmates into child correctional institutions is separated according to their status, namely criminal children, national children and civilian children. The difference in status is the basis for differentiating the coaching carried out against them." 22

Children should also have the right to get proper education and freedom to play with other children of their age, as stated in Law No. 39 of 1999 concerning Human Rights Article 60 and Article 61:

21 Pasal 28 B Ayat I \& Ayat 2 UndangUndang Dasar Republik Indonesia 1945.

22 Undang-undang Republik Indonesia Nomor 12 Tahun 1995 tentang Pemasyarakatan 
Article 60 (1) Every child has the right to get education in terms of his personal development in accordance with his interests, talents, and his level of intelligence

(2) Every child has the right to seek, receive and provide information in accordance with his level of intellectuality and age for the sake of his development as long as it conforms to the decency values

Article 61 Every child has the right to rest, play with other children of their age, and be creative according to their interests, talents, and level of intelligence for the sake of their development

Regarding the child inmates coaching placed in Correctional Institutions that are not child correctional institutions, an extra attention needs to be provided because children are vulnerable to imitate others, especially in their social environment. In fact, even though Law Number 12 of 1995 concerning Corrections has explained the separation of child and adult inmates, as well as Law Number 39 of 1999 concerning Human Rights, and Law Number 11 of 2012 (Law on child criminal justice system) and Law of the Republic of Indonesia Number 35 of 2014 concerning amendments to Law number 23 of 2002 concerning child protection which aims to protect human rights especially the rights of child inmates, but there are still child inmates in Class II-B Correctional Institution in Langsa City which is known as adult correctional institution occupied by male and female inmates.

In terms of the implementation of inmates coaching in the Correctional Institution, it has been adjusted to the Decree of the Minister of Justice No. M,02-PK.04.10 of 1990, concerning inmates coaching pattern which consists of 2 (two) parts, namely personality and selfreliance coaching. The Correctional System is implemented in order to help inmates to improve themselves to become better human beings and do not repeat criminal acts so that they can be accepted in their communities. For that reason, to achieve the optimal guidance in correctional institutions, the Government has formulated Law Number 12 of 1995 concerning Corrections in which it is explained that correctional coaching is carried out based on the principles, namely: a. Guidance; b. Treatment and service equality: c Education and guidance: d. Respect for human dignity: e. Losing independence is the only suffering; and f. Guarantee to keep in touch with families and certain people. ${ }^{23}$ In addition, according to Article 12 Paragraph (1) Law Number 12 of 1995 concerning Corrections, it is stated that the inmates coaching in correctional institutions is carried out on the basis of age, gender, length of sentence imposed, type of crime, and other criteria according to the needs or development of coaching. If we look at Article 12 of Law Number 12 of 1995 concerning Corrections, inmates should be then placed and guided based on their characteristics as mentioned above, so that the objectives of coaching can be achieved. ${ }^{24}$ With the current situation and condition in Class II-B correctional Institution in Langsa City which is over capacity, it can be confirmed that coaching will not be realized properly.

On the other hand, the implementation of personality coaching is carried out through various coaching, such as religious awareness, national and state awareness, intellectual ability, and legal awareness coaching. Moreover, the self-reliance coaching is provided through various programs, including:

1. Skills to support independent businesses, such as handicrafts, home industries, repairing machines and electronic equipment, etc. Skills to support smallscale industrial businesses, for example, processing rattan into household furniture, brick and roof tile making, etc.;

2. Skills developed in accordance with their talents, for example, some child inmates have talent in art, so they can join artists'

\footnotetext{
${ }^{23}$ Undang-undang Republik Indonesia Nomor 12 Tahun 1995 tentang Pemasyarakatan

24 RH Abdullah , Urgensi Penggolongan Narapidana Dalam Lembaga Pemasyarakatan Fiat Justisia Jurnal Ilmu Hukum Volume 9 No. 1, Januari-Maret 2015. .Fh.Unila. , Lampung , pp.55 diakses tanggal 9 maret 2018
} 
associations to develop their talents as well as earn a living;

3. Skills to support industrial businesses. Inmates, especially child inmates, should be guided in accordance with their talents and interests. Besides, the coaching provided should be positive and do not just kill the time. It should support their selfimprovement. ${ }^{25}$

Yet, in fact, the nature of coaching is still based on the principle and system of imprisonment, so that the institution used as a coaching place is a prison for inmates and a state education house for guilty children. This leads to the fact that the expected conditions cannot be realized properly, as it is proven in Class II-B Correctional Institution of Langsa City where the child inmates do not get the skills they deserve to as child inmates who are placed in child correctional institutions. They seem only to run sanctions because they are inmates; they are just waiting for the criminal period sentenced to him. Thus, it can be clearly seen that child inmates coaching in Class II-B correctional institutions of Langsa City is only eligible for adult inmates.

\section{Efforts Done to Overcome Constraints in the Implementation of Child Inmates Coaching in Class II-B Correctional Institution of Langsa City}

It is known that correctional institution of Langsa city is a correctional institution consisting of adult inmates, male and female inmates, as well as child inmates. The latest data of Class II-B correctional institution shows that there are 449 inmates. It means that it is over capacity of $210^{26}$ because according to the provisions, class II-B correctional institution is worth as many as 145 people so that this condition shows an over capacity of 210 people $^{27}$. Thus, the efforts that should be done to overcome this problem are: decreasing the number of inmates which is overcapacity in

\footnotetext{
25 Keputusan Menteri Kehakiman RI No.M,02PK.04.10 Tahun 1990,tentang Pola Pembinaan Narapidana dan tahanan

26 Lapas Kelas IIB Kota Langsa, Hasil laporan_monthly_penghuni_rutan_lapas terbaru.xls tahun 2017 di akses tanggal 7 februari 2018

27 Wawancara dengan Bapak. T. Dermawan. S.H.,M.H., sebagai seksi giat kerja di lembaga pemasyarakatan kelas II-B Kota Langsa , Pada tanggal 16 Desember 2016
}

Class II-B Correctional Institution of Langsa City, increasing the number of correctional officers, providing educational (intellectual) coaching through formal education to inmates, especially to child inmates since they are still in school age, developing legal awareness, and providing guidance on spiritual and physical health so that they can live a healthy life.

Furthermore, another effort that can be done is coaching by giving jobs so that inmates can work and earn money. This can only be happened if the correctional institution works with relevant agencies, such as the Employment Assistance Center (BLK) and other job training. Through this kind of coaching, the child inmates can live in a more meaningful life because they can earn money as well as develop their skills. By having such skills, the child inmates will not be confused when living in the society because they are able to work and earn money. Besides, the coaching which is held out of the correctional institution, namely the provision of assimilation, also needs to be done for child inmates before they actually end up serving sentences, with the hope that they can return and be well received in the communities.

\section{CONCLUSION}

Based on the description, it was concluded that; the implementation of child inmates coaching in Class II-B Correctional Institutions of Langsa City is based on legislation, namely Implementation of Integrated Coaching which refers to the Decree of the Minister of Justice of RI Number M,02PK.04.10 of 1990 concerning Personality and Self-Reliance Coaching for Child Inmates in Correctional Institutions. However, in Class IIB Correctional Institution of Langsa city, the nature of coaching is still based on the principle and system of imprisonment, so that the institution used as a coaching place is a prison for inmates and a state education house for guilty children. This leads to the fact that the expected conditions cannot be realized properly, as it is proven in Class II-B Correctional Institution of Langsa City where the child inmates do not get the skills they deserve to as child inmates who are placed in child correctional institutions.

Some efforts that should be done to overcome this problem are: decreasing the number of inmates which is overcapacity in 
Class II-B Correctional Institution of Langsa City, increasing the number of correctional officers, providing educational (intellectual) coaching through formal education to inmates, especially to child inmates since they are still in school age, developing legal awareness, and providing guidance on spiritual and physical health so that they can live a healthy life.

\section{SUGGESTION}

Based on the description above, it is suggested to the government to think about and plan how to properly build a Correctional Institution in which the facilities and infrastructure of the Correctional Institution are adjusted to the principles of legislation because Class II-B Correctional Institution of Langsa city is over capacity. The over capacity will lead to the condition where the inmates coaching cannot be implemented so that the concept of coaching cannot run optimally, especially for child inmates. According to Decree of the Minister of Justice of RI Number M,02-PK.04.10 of 1990 concerning inmates coaching pattern (Integrated Coaching), namely Personality and self-reliance coaching for inmates and child inmates, inmate coaching can only be implemented if the facilities in Class IIB Correctional Institution of Langsa city are accommodated in accordance with the rules determined by the legislation.

\section{REFERENCES}

A. Josias Simon R -Thomas Sunaryo , (2010) Studi Kebudayaan Lembaga Pemasyarakatan Indonesia, Bandung, Lubuk Agung.

C. Jisman Samosir, (2016). Penologi dan Pemasyarakatan, Bandung. Nuansa Aulia,

Dwidja Priyatmo, (2006), Sistem Pelaksanaan Pidana penjara di Indonesia, Bandung, Refika Aditama,

Hadi Supeno, (2010) , Kriminalisasi Anak, Jakarta, Gramedia Pustaka Utama.

Haris Budiman dan Nopa Arisyana (2017). Implementasi Pengamanan Pada Lembaga Pemasyarakatan Dan Rumah Tahanan Negara (Studi Di Lembaga Pemasyarakatan Kelas Iia Kuningan) ISSN 2354-5976 Vol. 04 Nomor 02 Juli 2017, pp. 77-85.

Hoetomo M.A, (2005). Kamus Lengkap Bahasa Indonesia dilengkapi dengan pedoman umum Ejaan Bahasa Indonesia (EYD) Tata Bahasa-Pemahaman Bahasa Kosakata Kesusastraan, Surabaya, Mitra Pelajar

Komar Hidayat, Yunusrul Zen dan Diding Rahmat. (2017). Analisis Yuridis Terhadap Kebijakan Diversi Pemerintah Daerah Dalam Perlindungan Anak Di Kabupaten Kuningan, Jurnal Unifikasi, Vol. 04, Nomor 02, Juli 2017, Kuningan, FH. Uniku.

Kristina Sitanggang, Pembinaan Terhdapa Narapidana (Studi di Lembaga Pemasyarakatan Kelas II B Kota Langsa) https://jurnal.usu.ac.id/index.php/jmpk/ar ticle/view/8184/3544 diakses pada tgl 6 februari 2018

Lembaga Pemasyarakatan Kelas II B, Kota Langsa. Hasil laporan_monthly_penghuni_rutan_lapas terbaru.xls tahun 2017 di akses tanggal 7 februari 2018

Mahmul Siregar, Marlina, Rosmalinda, Azmiati Zuliah, (2007), Pedoman Praktis Melindungi Anak dengan Hukum Pada Situasi Imergensi dan Bencana Alam, Medan. Pusat Kajian dan Perlindungan Anak

Marlina, (2009),Peradilan Pidana Anak di Indonesia, Pengembangan konsep diversi dan Restorasi Justice, Bandung. Refika Aditama.

R, wiyono, (2016), Sistem Peradilan Pidana Anak Di Indonesia, Sinar Grafika, Jakarta Timur.

Rahmat Hi. Abdullah (2015), Urgensi Penggolongan Narapidana Dalam Lembaga Pemasyarakatan Fiat Justisia Jurnal Ilmu Hukum Volume 9 No. 1, Januari-Maret 2015. .Fh.Unila. Lampung, pp.55.

Syamsul Hilal. 1979). “P4 adalah Mutlak perlu Bagi Setiap Aparatur Pemasyarakatan Sebagai Pelaksana Dan Sebagai Abdi Masyarakat, Majelis Pemasyarakatan, 21 Maret 1979, pp. 18 di akses tanggal 7 februari 2018

Soejono, Soerjono dan Sri Mamuj (2010). Penelitian Hukum Normatif Suatu Tinjauan Singkat, Jakarta ,Raja Grafindo Persada, 